\title{
Unravelling the cooling history of HT- UHT rocks from South India: New evidences from LA-ICPMS analysis of rutiles
}

\section{J. AMAL DEV, NILANJANA SORCAR AND J.K. TOMSON}

Isotope Geochemistry Facility, National Centre for Earth Science Studies

Presenting Author: amaldevj@gmail.com

The Southern Granulite Terrain (SGT) of south India comprises of distinct polymetamorphic terrains with prolonged crustal evolution history ranging from Early Archean to Late Neoproterozoic, preserving evidences for polyphase deformation, multiple tectonothermal and multiphase exhumation histories. SGT occupies the central position in Gondwana supercontinent reconstruction models. Within the SGT, the largest crustal domain known as Madurai Block (MB) preserves extensive high $\mathrm{Mg}-\mathrm{Al}$ granulite facies rocks which are associated with a wide range of lithological assemblages with distinct mineral association, indicative of UHT metamorphism preserved at 550 Ma. This study presents LA-ICPMS U-Pb and trace element data on rutile grains within charnockites, metapelites and mafic granulites. Rutile is a robust geochronometer and is stable over a large P-T range and hence is useful in reconstructing P-T histories of polydeformed granulite terrains. $\mathrm{U}-\mathrm{Pb}$ dating on rutiles in seven samples provide Silurian cooling ages between 420 and 480 Ma. Rutile grains $(\sim 100-300 \mu \mathrm{m})$ also exhibit superchondritic concentrations for $\mathrm{V}, \mathrm{Zr}, \mathrm{Nb}, \mathrm{Hf}$, Th and $\mathrm{U}$ along with enriched rare earth elements (REE). $\mathrm{Nb}-\mathrm{Cr}$ trace element discrimination diagram suggest growth of rutile in pelitic rocks during metamorphism. The strong positive correlation of $\mathrm{Zr}$ with Hf suggests decoupling of $\mathrm{Zr}$ and Hf over other HFSE elements, probably during retrogression. Zr-in-rutile thermometry calibration yields temperature estimates over the range of $800^{\circ} \mathrm{C}$ and $1100^{\circ} \mathrm{C}$ suggesting retention of $\mathrm{Zr}$ concentrations corresponding to rutile growth under UHT conditions. The low closure temperature of $\mathrm{Pb}$ in rutile grains along with knowledge on the precise timing of HT-UHT metamorphism in the associated samples allowed the calculation of rate of cooling between $3^{\circ} \mathrm{C}-5^{\circ} \mathrm{C} / \mathrm{Ma}$ providing the first estimation of cooling rate for the terrain. The results have significant implication in understanding the tectonic and temporal evolution of SGT, classifying it as a classic slow-cooled granulite terrain. The results also signifies the robustness of rutile geochemistry using LA-ICPMS technique in deciphering the tectonothermal evolution of granulitic terrains. 